\title{
Is Bone Density a Success Criteria in Dental Implants
}

\author{
Urmi Agrawal $^{1 *}$, Md Jalaluddin ${ }^{2}$, Doyel Roy ${ }^{3}$ and Riddhi Awasthi ${ }^{1}$ \\ ${ }^{1}$ Post Graduate Trainee, Department of Periodontics and Oral Implantology, \\ Kalinga Institute of Dental Sciences, India \\ ${ }^{2}$ Professor, Department of Periodontics and Oral Implantology, Kalinga Institute of \\ Dental Sciences, India \\ ${ }^{3}$ Post Graduate Trainee, Department of Oral Medicine and Radiology, Kalinga \\ Institute of Dental Sciences, India \\ *Corresponding Author: Urmi Agrawal, Post Graduate Trainee, Kalinga Institute of \\ Dental Sciences, Bhubaneswar, Odisha, India.
}

Received: April 23, 2021

Published: May 26, 2021

(C) All rights are reserved by Urmi Agrawal., et al.

\begin{abstract}
In modern era, implant dentistry has become a choice of treatment for restoring the missing teeth. For a successful outcome the treatment procedure requires a series of patient-related and procedure-dependent parameters. The volume of bone available and bone quality plays a vital role in planning the surgical procedure, the type of implant, and in the success of the implant. Osseointegration is predicted by implant stability, which occurs in two levels i.e. primary and secondary stability. Primary stability is associated with the mechanical interlocking of an implant with the surrounding bone, which is affected by bone quality and quantity, surgical technique and implant type (length, width, surface texture). Secondary stability is the biological stability through bone regeneration and remodeling, which is affected by primary stability. Factors affecting the primary stability of implants can be classified into patient-related (bone quality and quantity) and non-patient related factors (implant design and surgical procedure. It has been found that in successfully osseointegrated implants despite of the surgical approaches (submerged or nonsubmerged) the initial bone loss usually starts at the crestal level. This review presents correlation and calculations of bone mineral density (BMD) or the marginal bone loss from gray value with assessments of bone quality and implant stability.
\end{abstract}

Keywords: Dental Implants; Bone Density; Primary Stability; Crestal Bone Loss; Primary Stability; Insertion Torque; CBCT

\section{Introduction}

In modern era, implant dentistry has become a choice of treatment for restoring the missing teeth. For a successful outcome the treatment procedure requires a series of patient-related and procedure-dependent parameters [1]. The volume of bone available and bone quality plays a vital role in planning the surgical procedure, the type of implant and in the success of the implant. As introduced by Branemark 1987, successful osseointegration is predicted by implant stability, which occurs in two levels i.e. primary and secondary stability. Primary stability is associated with the mechanical interlocking of an implant with the surrounding bone, which is affected by bone quality and quantity, surgical technique and implant type (length, width, surface texture). Secondary stability is the biological stability through bone regeneration and remodeling, which is affected by primary stability [2]. Factors affecting the primary stability of implants can be classified into patient re- 
lated (bone quality and quantity) and non-patient related factors (implant design and surgical procedure) [3].

\section{Bone density and implant stability}

Bone quantity can be described as the relative amount of surrounding cancellous and cortical portions and the density of the recipient site of the alveolar bone. Density has been used to describe the relative amount of marrow spaces present in a unit of bone tissue [4]. When compared the relationship between bone density and implant stability, bone density may affect implant healing time and the surgical procedure. It has been seen that the survival rates of implant primarily depends on the bone quality of the maxilla and mandible. Usually, the bone quality is dependent upon the arch and it is typical seen that the bone around the implant has better quantity and quality in the mandible than the maxilla. Maximum amount of bone density is usually in the mandibular anterior region, followed by the maxillary anterior and posterior mandible, and the least is found in the posterior maxilla. MacMillan and Parfitt have reported the etiology of bone density depends on the structural characteristics and variation of trabeculae in the alveolar regions of the jaws [5]. The biomechanical functions differ in the maxillary and mandibular jaws (Figure 1).

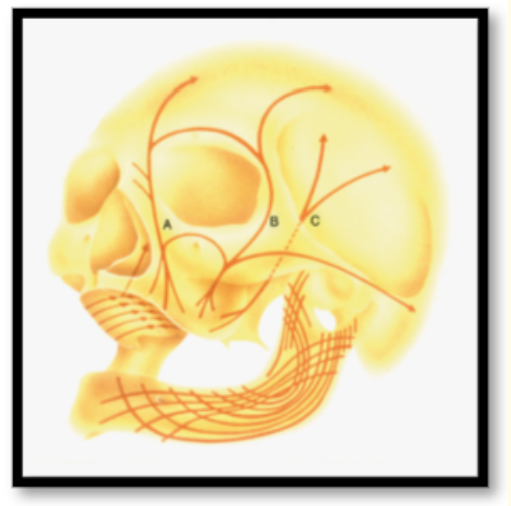

Figure 1: Maxilla is as a force distribution unit, and the mandible being a force absorption unit.

While the independent structure, mandible, is designed as a force-absorption unit and maxilla as the force distribution unit, where it has a thin cortical plate and fine trabecular bone supporting the teeth (Figure $2 \mathrm{a}$ and $2 \mathrm{~b}$ ).

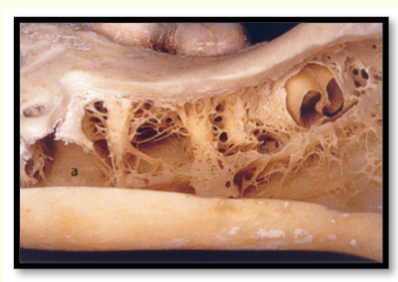

(a)

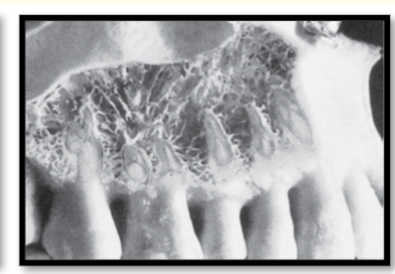

(b)
Figure 2: (a) Mandibular trabecular bone is more coarse compared with the maxilla. (b) Thin cortical plate and fine trabecular bone in maxilla.

Studies have shown that the mechanical behavior of bone seems to be an important factor in the successful osseointegration which determines the stability. There are several classification systems and procedures for assessment of bone quality and primary implant stability. Clinical methods are cutting torque/peak insertion torque and resonance frequency analysis (RFA) (Osstell, Integration Diagnostics) whereas radiographic methods consists of Computed tomography (CT) and Cone beam computed tomography (CBCT) [6]. The most widely accepted classification for assessment of bone density is by Misch (1999) [7].

\begin{tabular}{|c|c|c|c|}
\hline \multicolumn{4}{|c|}{ Bone density and common locations.* } \\
\hline $\begin{array}{l}\text { BONE } \\
\text { DENSITY } \\
\text { LEVELt }\end{array}$ & HISTOLOGY & USUAL LOCATION & $\begin{array}{l}\text { TACTILE } \\
\text { SENSE }\end{array}$ \\
\hline D1 & $\begin{array}{l}\text { Dense cortical } \\
\text { bone }\end{array}$ & $\begin{array}{l}\text { Anterior mandible (6 percent), } \\
\text { posterior mandible ( } 3 \text { percent) }\end{array}$ & $\begin{array}{l}\text { Drilling into } \\
\text { oak or maple }\end{array}$ \\
\hline D2 & $\begin{array}{l}\text { Dense to porous } \\
\text { cortical bone and } \\
\text { dense trabecular } \\
\text { bone }\end{array}$ & $\begin{array}{l}\text { Anterior mandible ( } 66 \text { percent), } \\
\text { posterior mandible ( } 50 \text { percent), } \\
\text { anterior maxilla ( } 25 \text { percent) }\end{array}$ & $\begin{array}{l}\text { Drilling into } \\
\text { pine or spruce }\end{array}$ \\
\hline D3 & $\begin{array}{l}\text { Porous cortical } \\
\text { bone and fine } \\
\text { trabecular bone }\end{array}$ & $\begin{array}{l}\text { Anterior maxilla ( } 65 \text { percent), } \\
\text { posterior maxilla ( } 50 \text { percent) }\end{array}$ & $\begin{array}{l}\text { Drilling into } \\
\text { balsa wood }\end{array}$ \\
\hline D4 & $\begin{array}{l}\text { Little cortical } \\
\text { bone and fine } \\
\text { trabecular bone }\end{array}$ & Posterior maxilla ( 40 percent) & $\begin{array}{l}\text { Drilling into } \\
\text { styrofoam }\end{array}$ \\
\hline \multicolumn{4}{|c|}{$\begin{array}{l}\text { * Sources: Misch }{ }^{14} \text { and Misch. }{ }^{16} \\
\dagger \text { D1: Dense cortical bone. D2: Dense-to-porous cortical bone and dense trabecular bone. } \\
\text { D3: Porous cortical bone and fine trabecular bone. D4: Little cortical bone and fine } \\
\text { trabecular bone. }\end{array}$} \\
\hline
\end{tabular}

Table 1: Bone density.

Several efforts have been made for the classification of bone density before implant placement on the basis of Hounsfield units (HUs) in CT examinations. Here HU represent the relative density 
of body tissues in realtion to a calibrated gray-level scale, which is precisely based on certain values for air $(-1000 \mathrm{HU})$, water $(0 \mathrm{HU})$ and bone density ( +1000 HU i.e. D1 bone type > $1250 \mathrm{HU}$; D2 bone type 850 - $1250 \mathrm{HU}$; D3 bone type 350 - $850 \mathrm{HU}$; D4 bone type 150 - $350 \mathrm{HU}$ [5,8]. Among imaging modalities used for bone density assessment, CBCT has advantages over conventional CT due to high image resolution and low radiation dose, and an advantage over micro CT, since it is being used clinically and not only for in vitro experiments. Moreover, CBCT showed comparable results to micro CT in assessing gray level distribution in human mandible [9]. Rios HF., et al. identified correlation between radiographic and tomographic measures supported the potential use of CBCT for assessing bone mineral density [10]. Bergkvist G., et al. (2010) did a study to compare the relationship between bone density before implant placement, primary stability and crestal bone loss at immediately implant placement after 1 year where they evaluated BMD, primary stability during and one year post surgery in both maxilla and mandible [11]. They found a correlation between bone density and implant stability.

\section{Insertion torque and bone density}

Primary stability and bone density are also evaluated on the basis of clinical methods (insertion torque method for primary stability). Studies have been carried out to investigate the optimum insertion torque, the minimum and the maximum limits. Neugebauer and associates [12] considered insertion torque above 50 $\mathrm{Ncm}$ to be higher and should not be exceeded, whereas a torque of $35 \mathrm{Ncm}$ was considered optimum for immediate loading protocol. While others suggested that insertion torque above $50 \mathrm{Ncm}$ could lead to higher peri-implant bone loss. Ottoni., et al. in their study suggested that a minimum of $32 \mathrm{Ncm}$ insertion torque was necessary for implants to achieve osseointegration. When the torque was $20 \mathrm{Ncm}$, nine out of 10 implants failed in their study. The average insertion torque in their study was $38 \mathrm{Ncm}$ [13]. Mahajan., et al. in his evidence based review was found that most of the studies used an insertion torque ranging 20 - $45 \mathrm{Ncm}$ [14].

Some researchers found that lower primary stability increased after osseointegration whereas in implants with high primary stability the post osseointegration value is decreased. Others showed that initially high primary stability (IT > 70) tended not to increase further with time, despite decreases in increased biological stability. The investigators concluded that initially low stability normally tends to increase with time owing to bone remodelling. Therefore, although very high primary stability is regarded as beneficial, particularly in situations in which the implant is expected to bear loads during osseointegration. The reason seems to be that after osseointegration owing to bone remodeling around the implant, the highest values neither increase nor decrease, whereas the lowest values tends to increase. A specific insertion torque value is still difficult to determine as the current evidence suggest the role of various factors affecting insertion torque while implant placements.

\section{Crestal bone loss and implant stability}

It has been found that in successfully osseointegrated implants despite of the surgical approaches (submerged or nonsubmerged) the initial bone loss usually starts at the crestal level [15]. Crestal bone loss has been surveyed to be a common phenomenon occurring after implant placement, and studies have shown that after successful implantation, the rate of crestal (marginal) bone loss is approximately $1.2 \mathrm{~mm}$ in the first year then eventually decrease to about $0.1 \mathrm{~mm}$ in following years [16]. In the field of implant dentistry the success not only depends on the osseointegration of the peri-implant interface but also in the outcome of esthetic and functional restoration. Success of prosthetic restoration by dental implant primarily depends on the maintenance of peri-implant bone level.

Postoperatively, CBCT assessment include mainly: (a) position of the implant fixture in the bone and its relation to surrounding anatomical landmarks, (b) bone density for assessing primary stability, (c) bone level of peri-implant interface and presence of any vertical bone loss. Stable peri-implant tissue levels surrounding the implant interface is required to achieve a favourable harmony with the dentition. According to various studies there are success criteria for different implant systems such as: absence of mobility of individual unattached implant when clinically tested and no radiographic evidence of peri-implant radiolucency at the peri-implant surfaces, absence of vertical marginal bone loss (if present should not exceed $1-2 \mathrm{~mm}$ at the first year of function). Harby., et al. (2016) [17] evaluated implant stability and crestal bone loss which was found to be increased in 20 implants at 6 months follow up interval. They also concluded that the crestal bone remodelling was reported to occur predominantly during the unloaded healing phase. 


\begin{tabular}{|c|c|}
\hline Author & Result \\
\hline $\begin{array}{l}\text { Roca millan., et al. } \\
\text { (2020) [18] }\end{array}$ & $\begin{array}{l}\text { No correlation found between } \\
\text { insertion torque and peri-implant } \\
\text { bone resorption }\end{array}$ \\
\hline $\begin{array}{l}\text { Rues S., et al. (2020) } \\
{[34]}\end{array}$ & $\begin{array}{l}\text { Found that primary implant stability } \\
\text { did not depend on total bone } \\
\text { thickness but tended to increase with } \\
\text { either increasing bone mineral density } \\
\text { or overall cortical bone thickness. }\end{array}$ \\
\hline $\begin{array}{l}\text { Makary C., et al. } \\
\text { (2019) [19] }\end{array}$ & $\begin{array}{l}\text { Concluded that matching implant } \\
\text { macro-geometry to bone density can } \\
\text { lead to adequate implant stability both } \\
\text { in hard and soft bone. }\end{array}$ \\
\hline $\begin{array}{l}\text { Mikić M., et al. (2019) } \\
{[20]}\end{array}$ & $\begin{array}{l}\text { Concluded that there was a } \\
\text { statistically significant strong } \\
\text { positive correlation between } \\
\text { HUs measured with CBCT } \\
\text { apparatus and ISQ values } \\
\text { where higher ISQ values } \\
\text { are related with higher HU } \\
\text { values. }\end{array}$ \\
\hline $\begin{array}{l}\text { Triches DF., et al. } \\
\text { (2019) [21] }\end{array}$ & $\begin{array}{l}\text { Concluded that the quality of bone } \\
\text { does affect the primary stability when } \\
\text { it measures with insertion torque and } \\
\text { all other methods used for the } \\
\text { assessment. }\end{array}$ \\
\hline $\begin{array}{l}\text { Gorantla SD., et al. } \\
\text { (2018) [22] }\end{array}$ & $\begin{array}{l}\text { Strong correlation between } \\
\text { the implant insertion torque } \\
\text { and ISQ values measured } \\
\text { with RFA. It was also } \\
\text { observed that implant } \\
\text { stability increased with } \\
\text { higher ISQ values. }\end{array}$ \\
\hline
\end{tabular}

Table 2: Brief Literature review on bone density, insertion torque and crestal bone loss.

\section{Conclusion}

Future research with larger sample size and multiple parameters, different surgical approach, split mouth comparative randomised controlled trial and well-designed research methodology comprising of broader range of implant dimensions, different surface coatings on implant with more control on confounding factors and other variables which are likely to affect acceptable osseointegration.

\section{Bibliography}

1. Beer A., et al. "Correlation of insertion torques with bone mineral density from dental quantitative CT in the mandible". Clinical Oral Implants Research 14 (2003): 616-620.

2. Swami V., et al. "Current trends to measure implant stability". The Journal of the Indian Prosthodontic Society 16 (2016): 124130.

3. Alkhader M., et al. "Predictability of bone density at posterior mandibular implant sites using cone-beam computed tomography intensity values". European Journal of Dentistry 11 (2017): 311-316.

4. Buck DL and Wheeler PW. "A density comparison of human alveolar and retromolar bone". The Angle Orthodontist 39 (1969): 133-136.

5. Misch CE. "Contemporary implant dentistry-E-Book". $1^{\text {st }}$ edition. Elsevier Health Sciences (2007).

6. Cavallaro Jr J., et al. "Clinical methodologies for achieving primary dental implant stability: the effects of alveolar bone density". Journal of the American Dental Association 140 (2009): 1366-1372.

7. Nackaerts O., et al. "Analysis of intensity variability in multislice and cone beam computed tomography". Clinical Oral Implants Research 22 (2011): 873-879.

8. Papaspyridakos P., et al. "Implant and prosthodontic survival rates with implant fixed complete dental prostheses in the edentulous mandible after at least 5 years: a systematic review". Clinical Implant Dentistry and Related Research 16 (2014): 705-717.

9. Alkhader M., et al. "Predictability of bone density at posterior mandibular implant sites using cone-beam computed tomography intensity values". European Journal of Dentistry 11 (2017): 311-316.

10. Rios HF., et al. "The use of cone-beam computed tomography in management of patients requiring dental implants: An American Academy of Periodontology best evidence review". Journal of Periodontology 88 (2017): 946-959. 
11. Bergkvist G., et al. "Bone density at implant sites and its relationship to assessment of bone quality and treatment outcome". The International Journal of Oral and Maxillofacial Implants 1 (2010): 25.

12. Neugebauer J., et al. "Peri-implant bone organization under immediate loading state. Circularly polarized light analyses: a minipig study". Journal of Periodontology 77 (2006): 152-160.

13. Ottoni JM., et al. "Correlation between placement torque and survival of single-tooth implants". The International Journal of Oral and Maxillofacial Implants 20 (2005): 5.

14. Mahajan A., et al. "Impact of implant insertion torque on success of implant-an evidence based review". IP International Journal of Periodontology and Implantology 3 (2020): 12-16.

15. Oh TJ., et al. "The causes of early implant bone loss: myth or science?" The Journal of Periodontology 73 (2002): 322-333.

16. Park JH., et al. "Analysis of factors affecting crestal bone loss around the implants". Journal of Korean Dental Science 3.1 (2009): 12-17.

17. Gamalat A H., et al. "Clinical and radiographic evaluation of the osseointegration, bone level, bone density around short dental implants in posterior atrophic maxilla". Alex Dent Jou 41 (2016): 78-85.

18. Roca-Millan E., et al. "Implant insertion torque and marginal bone loss: A systematic review and meta-analysis". International Journal of Oral Implantology 13.4 (2020): 345-353.

\section{Volume 5 Issue 6 June 2021}

(c) All rights are reserved by Urmi Agrawal., et al. 